УДК 81 '23

DOI: 10.33184/YVDK-2021-04-30.49

\author{
А.А. Кулыева (доц. БашГУ), \\ Д.Р. Гилязова (cm. преп. БашГУ)
}

\title{
ВЛИЯНИЕ ВЕРБАЛЬНЫХ И НЕВЕРБАЛЬНЫХ СРЕДСТВ, ИСПОЛЬЗУЕМЫХ МЕДИЙНЫМИ ПЕРСОНАМИ, НА ВОЗНИКНОВЕНИЕ КОНФЛИКТА.
}

Статья посвящена обзору примеров выступлений медийных личностей $и$ анализу речевьх действий, имеющих конфликтогенную основу. Рассматриваются языковые $и$ психологические средства и приемы, побуждаюшие к возникновению конфликтной реакции и несущие потенциал конфликта, а также методы предотвращчения агрессивной реакиии со стороны общественности.

Ключевые слова: речевое действие, целевая аудитория, конфликтогенный, конфликтная ситуачия, эмочиоональная речь, (не)вербальный, конфликтогенная реакция.

The article is devoted to the review of performances of media people and the analysis of speech actions having conflict basis. The article considers linguistic and psychological means and techniques that encourage the emergence of a conflict reaction and carry the potential for conflict, as well as methods for preventing an aggressive reaction from the public.

Key words: speech action, target audience, conflictogenic, conflict situation, emotional speech, (non)verbal, conflictogenic reaction.

События текущего года показали, какую тесную взаимосвязь и огромное влияние имеют СМИ и выступления отдельных личностей на все сферы общественной и частной жизни людей. Основной и неотъемлемой функцией СМИ с недавнего времени стала их воздействующая функция. Эта функция многослойна, разнонаправленна и её составляют множество различных элементов, создающих монолитную систему. Неотъемлемыми элементами этой функции является 
свод определённых правил, система знаков, в рамках которой «происходит модификация семантики и функций разных типов языковых единиц и стандартных речевых действий» [Шейгал 2000:20]. Язык СМИ сочетает в себе ценностные и оценочные, часто окрашенные эмоционально, компоненты, и эти составляющие доминируют над аргументационными и фактологическими компонентами.

Аргументация сегодня - это компонент, способный привлечь внимание адресанта своей простотой и весомостью, но только этого недостаточно. Превалирующую роль играет харизма оратора, его способность убеждать и заражать публику уверенностью в своей правоте, мотивировать и побуждать к действиям слушателей, и здесь хороши любые средства.

По определению А. А. Ивина, «аргументация обращена в первую очередь к разуму человека, который способен, рассудив, принять или отвергнуть это мнение» [Ивин 1997:7]. Поэтому цель оратора - расположить к себе аудиторию любыми методами и приёмами. Важно учитывать такие факторы как: выбор времени и места предъявления информации, социальный состав целевой аудитории, её настрой и степень восприимчивости.

Недавние выступления шведской экологической активистки Греты Тунберг на саммите в ООН не оставили равнодушными многих людей по всей планете. Что представляет из себя Грета? Школьница из Швеции, экологическая активистка, получившая международную известность после своего выступления в ООН. Хотя, казалось бы, она использовала весьма скользкий приём в своей обличительной и даже обвинительной речи. В своей крайне эмоциональной речи она весьма экспрессивно выражала целый шквал негативных эмоций и чувств: сожаление, разочарование, беспокойство, возмущение, гнев, негодование и злобу. Она озвучила весьма хлёсткие обвинения в бездействии, в притворстве. Основным трендом её речи стали обвинения лидеров государств в том, что «они украли её мечты, детство, что они повинны в смертях вокруг и массовом вымирании», фактически обвинив их попутно в пустословии, заботе об экономическом развитии и финансовом благополучии, в ущерб окружающей среде. Речь её изобиловала повторами, восклицательными предложениями, риторическими вопросами и усилительными конструкциями: «People are suffering. People are 
dying.», «How dare you!», «We will never forgive you». Структура выступления, его ритм были непривычны для аудитории ассамблеи $\mathrm{OOH}$, которая отличается весьма сдержанными, выдержанными в дипломатическом стиле выступлениями, монотонными спорами, где любое повышение тона и, тем более прямые обвинения, переход на личности под негласным запретом и воспринимаются как моветон. Явно прослеживается игра на контрасте. Обращение к «сильным мира сего» изобилует категоричными конструкциями как то: «right here, right now» (здесь $u$ сейчас), «draw the line» (nодвести черту), «How dare you pretend...» (как вы смеете притворяться...»).

В своей речи Грета Тунберг формирует оппозицию «You : We» (вы:мы), где вы (обвиняемые) - это политическая элита, люди, облечённые властью, которым приписываются характеристики притворщиков, предателей, лжецов и обманщиков, занимающихся пустословием и дающих щедрые обещания, призывая их к ответственности, мы (обвинители, истцы) - это молодёжь, сторонники Греты, в полной мере осознающие всю двуликость власть имущих и не желающая отныне молчать и мириться с текущим положением дел.

После довольно экспрессивных аргументов, Грета выдаёт в качестве железного аргумента статистическую информацию, заставляя задуматься о тщете всех усилий что-либо кардинально изменить какими-то техническими новинками («by some technical innovations»), т.к. планы вдвое сократить выброс $\mathrm{CO} 2$ в атмосферу в течении 10 последующих лет обещают снизить температуру лишь на $1.5 \%$...Но что грозит обвиняемым? Из уст оратора звучит страшная угроза «We will never forgive you». / «Мы вас никогда не простим». Может ли эта угроза иметь должное побуждающее воздействие на «обвиняемых»? Думается, ответ очевиден.

Грете Тунберг, не смотря на всю экспрессивность своей обвинительной речи, нечего предложить политической элите в качестве наказания за бездействие и обман...Можно констатировать, что, хотя свою речь и угрозы Грета адресовала власть предержащим, реальным адресатом стала молодёжь, на которую и было рассчитано это эмоциональное выступление. Не смотря на кажущуюся неопытность и искренность выступления, каждое слово её речи было тщательно продумано, акценты, 
повторы и паузы спланированы, венцом выступления стала выразительная мимика, периодически лицо, как от ударов тока, искажалось болезненными, страдальческими, презрительными, злобными, уродливыми и жуткими гримасами.

В ближайшее время пройдет конкурс «Евровидение2021» в Роттердаме, на котором выступит певица Манижа, которая представит нашу страну на конкурсе с песней «Russian Woman». Еe сценический образ вызывает различную реакцию у публики: одним она не нравится совсем: «Уродливое явление на российской эстраде с появлением таких маниж. $B$ таком абсолютно пустом и примитивном выступлении нет ничего содержательного и тем более "талантливого"», "песня хуже некуда позор!», а у других она вызывает положительную реакцию, они солидарны с ней и считают, что ее образ соответствует характеру наших русских женщин. «Мне кажется, что эта песня как раз подходит к этому конкурсу. Девушка движется отлично, да и слова соответствуют характеру наших женшин. Хватит уже зауньвных песен, завываюшчих, хватит плакаться», «У нее мошуный голос, прекрасная внешность. Молодые девушки хорочо понимают смысл этой песни. А проблема безотцуовщчины в России вполне реальная, не надо делать вид что ее нет». Манижа представляет в песне образ русской женщины, которая сильна во всех смыслах: «в горящую избу войдет, коня на скаку остановит». В словах песни отражается характер, образ сильной духом и физически русской женщины:«Every Russian woman needs to know. You're strong enough to bounce against the wall». Следует отметить, что текст песни похож на грубый холст с яркими, сделанными в хаотичном порядке мазками, он не отличается глубиной и продуманностью, именно грубость отталкивает многих. Существует мнение, что текст песни унижает русских женщин и в реальности не отражает менталитет современной русской женщины. Комментарии в социальных сетях довольно неоднозначные.

«Нормальный рэп. Кто как хочет, тот так $и$ понимает. Чем непонятней смысл, тем больше шансов на победу, или наоборот». Есть отзывы, что на основе текста создается общее впечатление о стране. «И это в Европе! Понятно сразу, что песня ерундовая. Не знаю, какие там у нее другие песни, но эта - просто не песня, а позор и пустыика». 
Необходимо подчеркнуть, что есть конфликтогенная реакция слушателей, считающих, что русская женщина представлена в вульгарной манере, многих оскорбляет и характер исполнения, в песне упомянуты некоторые стереотипные установки, бытующие в семьях России, они предназначены «для внутреннего пользования». Как подмечает Н.П.Пешкова в своей статье «находясь в информационной среде воздействующего типа, участники коммуникации зачастую пытаются защитить себя от «ненужной» информации, от «чужого влияния», от нежелательного «вторжения» в индивидуальное сознание», причины такого негативного ответа общества могут крыться в перечисленных Н.П. Пешковой. [Пешкова 2017:110]

Проанализировав ряд отзывов, можно сделать вывод, что сценическое поведение конкурсантки вызывает как положительные эмоции, так и отрицательные эмоции. Фразы, встречающиеся в тексте песни, вызывают конфликт: «Шо там хорохорится?... «Вороны, прошу отвалите-е»... «Эй, рюсский женшин». Подобные фразы способствуют проявлению агрессивной реакции у публики. Внешний вид и манера ее исполнения являются провоцирующими и способствуют зарождению конфликтной ситуации со стороны слушателей.

Следует сделать вывод, что любой яркий, неординарный образ медийной личности может стать источником конфликтной ситуации и спровоцировать агрессию со стороны общества. Привлекающий внимание имидж или конфликтогенное поведение, вербальное и невербальное, могут вызвать бурную реакцию и стать предметом многочисленных разбирательств.

\section{ЛИТЕРАТУРА}

1. Ивин А. А. Основы теории аргументации: учебник. М.: Владос, 1997. 352 с.

2. Пешкова Н.П. Лингвистический ландшафт полиэтнического города: особенности вербального воздействия. // Вопросы психолингвистики. - № 3 (33). - 2017. - С. 108-122.

3. Шейгал Е. И. Семиотика политического дискурса. Волгоград: Перемена, 2000. 368 с.

(С Кулыева А.А., Гилязова Д.Р., 2021 г. 